Ramanujam Karthikeyan, Ganapathy Marimuthu*, Murugesan Sooriyakumar, Ahmed S. BaHammam, David Warren Spence, Seithikurippu R. Pandi-Perumal, Gregory M. Brown and Daniel P. Cardinali

\title{
Per3 length polymorphism in patients with type 2 diabetes mellitus
}

\begin{abstract}
Background: A number of observations support the involvement of circadian clock genes in the regulation of metabolic processes. One of these circadian genes, Per3, exhibits a variable number tandem repeat length polymorphism, consisting of two alleles, namely four and five repeat alleles, in its exon 18 . The objective of this study was to examine the existence of Per3 variants in patients with type 2 diabetes mellitus (T2DM) as compared to a non T2DM control group.
\end{abstract}

Methods: Intravenous blood samples were collected to obtain white blood cells from 302 T2DM patients and 330 non-diabetic, age- and sex-matched, individuals. Per3 genotyping was performed on DNA by polymerase chain reaction.

Results: Frequency of five repeat allele was higher, and that of four repeat allele lower, in T2DM patients as compared to non-diabetic controls $\left(\chi^{2}=6.977, \mathrm{p}=0.0082\right)$

Conclusions: The results indicate an association of Per3 five repeat allele with T2DM occurrence and suggest that individuals with five repeat allele may be at a greater risk for T2DM as compared to those carrying the four repeat allele.

Keywords: circadian rhythms; clock gene; metabolism; Per3 polymorphism; type 2 diabetes mellitus.

\footnotetext{
${ }^{*}$ Corresponding author: Prof. Ganapathy Marimuthu, Department of Animal Behaviour and Physiology, School of Biological Sciences, Madurai Kamaraj University, Madurai 625 021, Tamil Nadu, India, Phone: +91-452-2459116 (Office), Mobile: +91-9791696463, Fax: +91-452-2459181, E-mail: emailboxgm@gmail.com Ramanujam Karthikeyan: Department of Animal Behaviour and Physiology, School of Biological Sciences, Madurai Kamaraj University, Madurai, India

Murugesan Sooriyakumar: Department of Medicine, Madurai Medical College, Madurai, India

Ahmed S. BaHammam: University Sleep Disorders Center, College of Medicine, National Plan for Science and Technology, King Saud University, Riyadh, Saudi Arabia

David Warren Spence: Independent Researcher, 652 Dufferin Street, Toronto, Canada

Seithikurippu R. Pandi-Perumal: Somnogen Canada Inc., Toronto, Canada
}

Gregory M. Brown: Centre for Addiction and Mental Health, University of Toronto, Toronto, Canada

Daniel P. Cardinali: Faculty of Medical Sciences, Department of Teaching and Research, Pontificia Universidad Católica Argentina, Buenos Aires, Argentina

\section{Introduction}

The mammalian circadian system is composed of a central pacemaker, located in the suprachiasmatic nucleus (SCN) of the hypothalamus, and peripheral clocks present in almost every cell in the organism [1]. The SCN master clock is synchronized by Zeitgebers (photic and non-photic). Non-photic Zeitgebers also affect peripheral oscillators found in organs such as the pancreas, liver, skeletal muscle, heart, adipose tissue, intestine, and retina [2-4].

Circadian clock genes are known to regulate circadian periodicity through a transcription-translation feedback loop, the circadian clock gene Per3 playing an essential role in such a feedback loop. Per3 consists of 21 exons of which the exon 18 contains a polymorphic repeat domain, with four (Per $3^{4}$ ) or five $\left(P e r 3^{5}\right)$ copies of a tandem repeat region with a length of $54 \mathrm{bp}$ sequence encoding 18 amino acids [5]. Several studies have reported associations of hPer3 alleles with a number of physiopathological conditions, including preference of timing in sleep/wake cycles $[6,7]$, delayed sleep phase syndrome (DSPS) [5-8], and sleep homeostasis [9]. In Per3 mutant mice, circadian period and phase underwent changes in liver and other peripheral tissues [10]. Per3 has also been reported to regulate adipocyte fate [11].

In humans, the onset of T2DM is recognized to be multifactorial and related to, among other processes, the timing and extent of food intake and physical exercise [12-14], sleep duration, and circadian desynchronization [15-18]. Yet, whether there is any association of the Per3 alleles with T2DM and obesity in humans remains to be explored. The objective of the study was to investigate the existence of Per3 length polymorphism in type 2 diabetes mellitus (T2DM) patients as compared to a group of sexand age-matched non-diabetic controls. 


\section{Materials and methods}

\section{Sampling subjects}

Blood samples were collected from 302 T2DM individuals (age $=50.7 \pm 10.3$ ) and 330 healthy non-T2DMindividuals (age $=49.9 \pm 9.1$ ) who served as controls. Among 302 T2DM individuals, 184 were males (age $=52.1 \pm 9.8$ ) and 118 were females (age $=48.8 \pm 10.8$ ). In controls, 184 were males (age $=50.4 \pm 8.9$ ) and 146 females (age=49.4 \pm 3.0 ). All patients were living in Madurai, Tamil Nadu, India. Type 1 diabetes patients were excluded from the study.

Control subjects were initially screened randomly based on plasma glucose fasting level below $99 \mathrm{mg} / \mathrm{dL}$ and were excluded from participation if they had diabetes or any family history of diabetes [19]. The individuals were categorized as T2DM based on the guidelines prescribed by the National Institute of Diabetes and Digestive and Kidney Diseases (NIDDK), Bethesda, MD, USA, http:// diabetes.niddk.nih.gov/DM/pubs/diagnosis/index.aspx). All the patients with diabetes were under usual medication. All the information with regard to the protocol was explained and written consents were obtained from participants. The guidelines for the ethical treatment of patients in chronobiological studies [20] were followed and the experimental protocol was reviewed and approved by the Institutional Ethical Committee of the Madurai Kamaraj University, Madurai, India.

\section{Per3 genotyping}

Genomic DNA was isolated from the blood samples using the phenol-chloroform method. The polymerase chain reaction (PCR) was performed using the specific primers as described in [21]. The PCR reaction was carried out in $10 \mu \mathrm{L}$ tubes containing $1 \mu \mathrm{L}$ of $1 \times \mathrm{PCR}$ reaction buffer, $0.5 \mu \mathrm{L}(0.5 \mathrm{mM})$ of dNTPs mix, $1.5 \mu \mathrm{L}$ (0.4 mM) Forward/ Reverse Primer mix, $0.05 \mu \mathrm{L}$ (0.025 U) Taq polymerase enzyme (Genet Bio, Daejeon, Korea), $2 \mu \mathrm{L}$ (100 ng) of genomic DNA and $4.95 \mu \mathrm{L}$ of Milli- $Q$ water. The PCR amplification conditions included an initial step of $94^{\circ} \mathrm{C}$ for $5 \mathrm{~min}, 40$ cycles of amplification $\left(94^{\circ} \mathrm{C}\right.$ for $30 \mathrm{~s}$, $60.6^{\circ} \mathrm{C}$ for $30 \mathrm{~s}, 72^{\circ} \mathrm{C}$ for $30 \mathrm{~s}$ ) and a final extension at $72^{\circ} \mathrm{C}$ for $5 \mathrm{~min}$. The resultant PCR products showed three genotypes based on their DNA size, characterized as: (i) Per $3^{5 / 5}$ homozygous allele (401 bp); (ii) Per $3^{4 / 4}$ homozygous allele (347 bp); and (iii) Per $3^{4 / 5}$ heterozygous allele (347 bp and $401 \mathrm{bp}$ ). Subsequently, 5\% of long repeat and short repeat alleles were sequenced for confirmation.

\section{Statistical analysis}

Distribution of four and five repeat allele frequencies in the population was determined using the Hardy-Weinberg exact test [22]. Deviation from Hardy-Weinberg equilibrium and the association of allele frequencies of four and five repeat alleles with T2DM and control were analyzed by Chi-square Testing using the Statistical Program for Social Science (SPSS) software (Version 20.0; IBM Corp, Armonk, NY, USA); $p$-values lower than 0.05 were taken as evidence of statistical significance.

\section{Results}

Table 1 summarizes genotype and allelic distribution of Per3 variants in both groups of individuals. Genotype distribution in the three groups was within the limits of Hardy-Weinberg equilibrium. No significant deviation was found between the observed and expected allele frequencies for T2DM and control groups ( $p>0.05$ ). The observed genotype frequencies in control and T2DM groups were 41.2\% and 33.8\% for Per3 homozygous four repeat allele (4/4), 47\% and 47.3\% for Per3 heterozygous allele (5/4) and $11.8 \%$ and $18.9 \%$ for Per3 homozygous five repeat allele (5/5), respectively. An increased prevalence of five repeat homozygotes was seen in T2DM patients as compared to non-diabetic controls (odds ratio $=1.95$, confidence interval 95\%=1.21-3.15, $\mathrm{p}=0.006$ ).

The allelic distribution of Per3 variants in both groups of individuals is summarized in Table 2. Frequency of five repeat allele was higher, and that of four repeat allele lower, in T2DM patients as compared to non T2DM individuals $\left(\chi^{2}=6.977, \mathrm{p}<0.0082\right)$.

\section{Discussion}

The foregoing results indicate that the Per3 five repeat allele could be related to T2DM occurrence and suggest

Table 1 Genotypic distribution of the 4-/5- length polymorphism of Per3 in type 2 diabetes mellitus (T2DM) patients and controls.

\begin{tabular}{lrrrr}
\hline Group & $\mathbf{n}$ & & & Genotype $^{\text {a }}$ \\
\cline { 2 - 5 } & & $\mathbf{4 - / 4 -}$ & $\mathbf{4 - / 5}$ & $\mathbf{5 - / 5}$ \\
\hline T2DM & 302 & 102 & 143 & 57 \\
Control & & $(34 \%)$ & $(47 \%)$ & $(19 \%)$ \\
& 330 & 136 & $(47 \%)$ & $(12 \%)$ \\
Odds ratio (95\% & & $(41 \%)$ & $1.23(0.87-1.73) \mathrm{p}=0.24$ & $1.95(1.21-3.15) \mathrm{p}=0.006$ \\
confidence interval) & & & \\
\hline
\end{tabular}

a-, 4-repeat allele; 5-, 5-repeat allele. 
Table 2 Four and Five repeat allele distribution of Per3 in type 2 diabetes mellitus (T2DM) patients and controls.

\begin{tabular}{|c|c|c|c|c|c|}
\hline \multirow[t]{2}{*}{ Group } & \multirow[t]{2}{*}{$\mathbf{n}$} & \multicolumn{2}{|r|}{ Allele (\%) } & \multirow[t]{2}{*}{$\mathbf{X}^{2}$} & \multirow[t]{2}{*}{ p-Value } \\
\hline & & 4- & 5- & & \\
\hline T2DM & 302 & $347(57 \%)$ & 257 (43\%) & & \\
\hline Control & 330 & $427(65 \%)$ & $233(35 \%)$ & 6.977 & 0.0082 \\
\hline \multirow{2}{*}{$\begin{array}{l}\text { Odds ratio ( } 95 \% \\
\text { confidence interval) }\end{array}$} & & $0.74(0.59-0.92)$ & $1.36(1.08-1.71)$ & IC 95\%(1.081726-1.703075) & \\
\hline & & $\mathrm{p}<0.01$ & $\mathrm{p}<0.01$ & & \\
\hline
\end{tabular}

4-, 4-repeat allele; 5-, 5-repeat allele.

that individuals with five repeat allele could be at a greater risk for T2DM as compared to individuals carrying the four repeat allele. Previously, a single nucleotide polymorphism (SNP) identified in CRY2, another circadian clock gene, but not in PER3, correlated with T2DM [23]. The distribution of Per3 alleles and genotypes were found to be in Hardy-Weinberg equilibrium, suggesting that genotypic and allele frequencies are constant in the population.

Although knowledge of Per3's role as a component of time-keeping system in humans is limited, a number of reports indicate that $h P e r 3$ can be involved in the functioning of sleep $[8,24,25]$ and of certain metabolic processes $[11,26]$. Per3 alleles seem to influence sleep homeostasis and sleep/wake timing in individuals $[8,9]$ and a strong correlation has been found between the amount of sleep time and Per3 protein secretion in individuals [27]. Compared to four repeat individuals, five repeat individuals tend to experience a greater sense of sleep pressure and, further, tend to demonstrate a poorer cognitive performance when they are sleep deprived. Interestingly, five repeat Per3 allele has been linked to DSPS in a Brazilian population [7] as well as to a delayed acrophase of melatonin secretion [27]. Exposure of blue light decreased melatonin levels to a greater extent in individuals carrying the five repeat Per3 allele than in four repeat individuals [28]. In contrast, no correlation has been found between Per3 genotypes and preference of sleep/wake timing $[29,30]$.

A recent study attributed a major role of Per3 in the time keeping of peripheral oscillators present in the liver [10]. Per3 could also have a possible functional role in the regulation of adipogenesis as constitutive expression of Per3 blocked the process of adipogenesis in mesenchymal stem cells, whereas elimination of Per3 promoted it [11]. Moreover, Per3 mutant mice exhibited a remarkable difference in their body mass and body composition [26] and had more adipose tissue content than wild type mice [11].
Per3 is down regulated when cells are maintained under gluco-lipotoxic conditions in vitro [31].

A link between prolonged sleep disturbance and the increasing worldwide prevalence of the metabolic syndrome has been proposed [15, 17, 32]. For instance, it has been reported that clock gene expression is impaired in individuals with metabolic syndrome, and, further, that impairments in transcript levels of PER3 in human leukocytes occur in diabetic subjects and gestational diabetic women [33, 34]. Interestingly, mRNA of PER3 has been found to be inversely proportional to the glycated hemoglobin levels in T2DM patients [31, 34]. Taken together, these findings suggest that impaired Per3 may influence glucose metabolism.

Presence of three phenotypic variants in Per3 could be due to differential phosphorylation of proteins. The polymorphic repeat consists of a region of putative phosphorylation sites and phosphorylation would give rise to phenotype difference in individuals. Third repeat insertion/deletion would influence the phosphorylation level, thus modifying the behavior of an individual resulting in three different behavioral phenotypes [6].

The present study had several limitations that need to be considered in any interpretations of its findings. Besides its preliminary nature and the necessity for it to be confirmed in larger samples of patients and in different ethnic populations, the present study did not investigate the association between the onset of T2DM, body mass index and alcohol dependence among patients and the genotypic variants of Per3. Such a study is needed to substantiate the existence of a direct link between the polymorphic variants and their possible association with diabetes. Moreover it remains to be explored whether Per3 directly influences T2DM or indirectly through altered sleep/wake cycles or by any other unknown mechanism that remains unidentified. Indeed, besides circadian changes, other causative factors for the onset of T2DM must be considered, including insulin resistance in liver 
and abnormal adipogenesis [35], less physical inactivity [14], sleep loss [17, 36], sedentary lifestyle [14, 37], and high amount of food intake and/or high calorie food consumption [16]. In any event, the findings reported herein are compatible with the hypothesis that Per3 five repeat allele is associated with a greater risk of T2DM.

Acknowledgements: First and foremost, we are extremely grateful to the study participants who took the time from their busy schedules to participate in the study. Without their participation and feedback, this study would not have been possible. We sincerely thank P. Kumarasamy, S. Chandrasekar, Anbarasan, Vasavi, S. Vignesh, Parthiban, Sowbar, Mukilan, and M. Stalin Raja for their help and assistance. The authors sincerely acknowledge the financial support received from various programs including DST-PURSE, UGC-CAS, NRCBS, UGC-Genomics Program, and ANPCYT, Argentina (PICT 2012-0984). R. Karthikeyan acknowledges the UGC for providing Meritorious fellowship. However, the funders had no role in study design, data collection and analysis, decision to publish, or preparation of the manuscript. DPC is a Senior Investigator, CONICET, Argentina.

\section{Conflict of interest statement}

The authors have read the journal's policy and have the following potential conflicts: S.R. Pandi-Perumal is a stockholder and the President and Chief Executive Officer of Somnogen Canada Inc., a Canadian Corporation. He declares that he has no competing interests that might be perceived to influence the content of this article. This does not alter the authors' adherence to all the journal policies. All remaining authors declare that they have no proprietary, financial, professional, nor any other personal interest of any nature or kind in any product or services and/ or company that could be construed or considered to be a potential conflict of interest that might have influenced the views expressed in this manuscript.

Received September 2, 2013; accepted November 14, 2013; previously published online December 14, 2013

\section{References}

1. Mazzoccoli G, Pazienza V, Vinciguerra M. Clock genes and clock-controlled genes in the regulation of metabolic rhythms. Chronobiol Int 2012;29:227-51.

2. Maywood ES, Mrosovsky N, Field MD, Hastings MH. Rapid downregulation of mammalian period genes during behavioral resetting. of the circadian clock. Proc Natl Acad Sci USA 1999;96:15211-6.

3. Marcheva B, Ramsey KM, Bass J. Circadian genes and insulin exocytosis. Cell Logist 2011;1:32-6.

4. Vaze KM, Sharma VK. On the adaptive significance of circadian clocks for their owners. Chronobiol Int 2013;30:413-33.

5. Ebisawa T, Uchiyama M, Kajimura N, Mishima K, Kamei Y, Katoh M, Watanabe T, Sekimoto M, Shibui K, Kim K, Kudo Y, Ozeki Y, Sugishita M, Toyoshima R, Inoue Y, Yamada N, Nagase T, Ozaki N, Ohara O, Ishida N, Okawa M, Takahashi K, Yamauchi T. Association of structural polymorphisms in the human period3 gene with delayed sleep phase syndrome. EMBO Rep 2001;2:342-6.

6. Archer SN, Robilliard DL, Skene DJ, Smits M, Williams A, Arendt J, von Schantz SM. A length polymorphism in the circadian clock gene Per3 is linked to delayed sleep phase syndrome and extreme diurnal preference. Sleep 2003;26:413-5.

7. Pereira DS, Tufik S, Louzada FM, Benedito-Silva AA, Lopez AR, Lemos NA, Korczak AL, D’Almeida V, Pedrazzoli M. Association of the length polymorphism in the human Per3 gene with the delayed sleep-phase syndrome: does latitude have an influence upon it? Sleep 2005;28:29-32.

8. Archer SN, Carpen JD, Gibson M, Lim GH, Johnston JD, Skene DJ, von Schantz M. Polymorphism in the PER3 promoter associates with diurnal preference and delayed sleep phase disorder. Sleep 2010;33:695-701.
9. Viola AU, Archer SN, James LM, Groeger JA, Lo JC, Skene DJ, von Schantz M, Dijk DJ. PER3 polymorphism predicts sleep structure and waking performance. Curr Biol 2007;17:613-8.

10. Pendergast JS, Niswender KD, Yamazaki S. Tissue-specific function of Period3 in circadian rhythmicity. PLoS One 2012;7:e30254.

11. Costa MJ, So AY, Kaasik K, Krueger KC, Pillsbury ML, Fu YH, Ptacek LJ, Yamamoto KR, Feldman BJ. Circadian rhythm gene period 3 is an inhibitor of the adipocyte cell fate. J Biol Chem 2011;286:9063-70.

12. Hatori M, Vollmers C, Zarrinpar A, DiTacchio L, Bushong EA, Gill S, Leblanc M, Chaix A, Joens M, Fitzpatrick JA, Ellisman MH, Panda S. Time-restricted feeding without reducing caloric intake prevents metabolic diseases in mice fed a high-fat diet. Cell Metab 2012;15:848-60.

13. Arble DM, Bass J, Laposky AD, Vitaterna MH, Turek FW. Circadian timing of food intake contributes to weight gain. Obesity (Silver Spring) $2009 ; 17: 2100-2$.

14. Maury E, Ramsey KM, Bass J. Circadian rhythms and metabolic. syndrome: from experimental genetics to human disease. Circ Res 2010;106:447-62.

15. Yaggi HK, Araujo AB, McKinlay JB. Sleep duration as a risk factor for the development of type 2 diabetes. Diabetes Care 2006;29:657-61.

16. Gangwisch JE, Heymsfield SB, Boden-Albala B, Buijs RM, Kreier F, Pickering TG, Rundle AG, Zammit GK, Malaspina D. Sleep duration as a risk factor for diabetes incidence in a large U.S. sample. Sleep 2007;30:1667-73.

17. Knutson KL, Spiegel K, Penev P, Van Cauter E. The metabolic consequences of sleep deprivation. Sleep Med Rev 2007;11:163-78. 
18. Spiegel K, Knutson K, Leproult R, Tasali E, Van Cauter E. Sleep loss: a novel risk factor for insulin resistance and Type 2 diabetes. J Appl Physiol 2005;99:2008-19.

19. Lewis CM, Knight J. Introduction to genetic association studies. Cold Spring Harb Protoc 2012;2012:297-306.

20. Portaluppi F, Smolensky MH, Touitou Y. Ethics and methods for biological rhythm research on animals and human beings. Chronobiol Int 2010;27:1911-29.

21. Artioli P, Lorenzi C, Pirovano A, Serretti A, Benedetti F, Catalano M, Smeraldi E. How do genes exert their role? Period 3 gene variants and possible influences on mood disorder phenotypes. Eur Neuropsychopharmacol 2007;17:587-94.

22. Rodriguez S, Gaunt TR, Day IN. Hardy-Weinberg equilibrium testing of biological ascertainment for Mendelian randomization studies. Am J Epidemiol 2009;169:505-14.

23. Kelly MA, Rees SD, Hydrie MZ, Shera AS, Bellary S, O'Hare JP, Kumar S, Taheri S, Basit A, Barnett AH. Circadian gene variants and susceptibility to type 2 diabetes: a pilot study. PLoS One 2012;7:e32670.

24. Hasan S, van der Veen DR, Winsky-Sommerer R, Dijk DJ, Archer SN. Altered sleep and behavioral activity phenotypes in PER3-deficient mice. Am J Physiol Regul Integr Comp Physiol 2011;301:R1821-30.

25. Bae K, Jin X, Maywood ES, Hastings MH, Reppert SM, Weaver DR. Differential functions of mPer1, mPer2, and mPer3 in the SCN circadian clock. Neuron 2001;30:525-36.

26. Dallmann R, Weaver DR. Altered body mass regulation in male mPeriod mutant mice on high-fat diet. Chronobiol Int 2010;27:1317-28.

27. Archer SN, Viola AU, Kyriakopoulou V, von SM, Dijk DJ. Interindividual differences in habitual sleep timing and entrained phase of endogenous circadian rhythms of BMAL1, PER2 and PER3 mRNA in human leukocytes. Sleep 2008;31:608-17.
28. Chellappa SL, Viola AU, Schmidt C, Bachmann V, Gabel V, Maire M, Reichert CF, Valomon A, Gotz T, Landolt HP, Cajochen C. Human melatonin and alerting response to blue-enriched. light depend on a polymorphism in the clock gene PER3. J Clin Endocrinol Metab 2012;97:E433-7.

29. Osland TM, Bjorvatn BR, Steen VM, Pallesen S. Association study of a variable-number tandem repeat polymorphism in the clock gene PERIOD3 and chronotype in Norwegian university students. Chronobiol Int 2011;28:764-70.

30. Voinescu BI, Coogan AN. A variable-number tandem repeat polymorphism in PER3 is not associated with chronotype in a population with self-reported sleep problems. Sleep Biol Rhythms 2012;10:23-6.

31. Stamenkovic JA, Olsson AH, Nagorny CL, Malmgren S, DekkerNitert M, Ling C, Mulder H. Regulation of core clock genes in human islets. Metabolism 2012;61:978-85.

32. Wolk R, Somers VK. Sleep and the metabolic syndrome. Exp Physiol 2007;92:67-78.

33. Ando H, Takamura T, Matsuzawa-Nagata N, Shima KR, Eto T, Misu H, Shiramoto M, Tsuru T, Irie S, Fujimura A, Kaneko S. Clock gene expression in peripheral leucocytes of patients with type 2 diabetes. Diabetologia 2009;52:329-35.

34. Pappa KI, Gazouli M, Anastasiou E, Iliodromiti Z, Antsaklis A, Anagnou NP. Circadian clock gene expression is impaired in gestational diabetes mellitus. Gynecol Endocrinol 2013;29:331-5.

35. Lin Y, Sun Z. Current views on type 2 diabetes. J Endocrinol. 2010;204:1-11.

36. Kawakami N, Takatsuka N, Shimizu H. Sleep disturbance and onset of type 2 diabetes. Diabetes Care 2004;27:282-3.

37. Zimmet $\mathrm{P}$, Arblaster M, Thoma K. The effect of westernization on native populations: studies on a Micronesian community with a high diabetes prevalence. Aust N Z J Med 1978;8:141-6. 